\title{
The Construction of the Status of "Victim" through the Victims and Land Restitution Law in Colombia - (re)encounters and confrontations with a legal category
}

\author{
Alma Cielo Ochoa Sterling \\ Universidade de Panthéon-Surbone
}

\section{Introduction}

The victim as object has been studied from diverse approaches in various works. From macrosociology studies on social mobilization (Mathieu and Lefranc, 2009) and their awarenessraising mechanisms for the cause (Traïni, 2009), to micro-social work that has focused on the (co)construction of victim status by different actors, the victim as an object has been studied in Europe and the Anglo-Saxon world alike. Furthermore, the victim as an object has been analyzed in the sphere of international organizations and NGOs through the study of the uses of transitional justice, where sometimes the legal category of "victim" is central. Additionally, there are works linked to the sociology of law, which have focused on the study of the place of the victim in civil and criminal proceedings (Barbot and Dodier, 2014).

Both in Colombian literature and in Latin American literature, analyzes have focused on the study of the victim status in democratic transitions (Schelotto, 2015) and work on social mobilizations of victims for the recognition of rights (Cepeda, 2006). Political science and the sociology of organizations, among others such as social psychology, have also contributed to the literature on the victim as an object, through studies on the historical and collective memory of certain social movements linked to victims (Jaramillo, 2016; Historical Memory Center).

In the above-mentioned cases, The victim as an object of study has been studied through theories of the new social movements, studying the demands and repertoires of action of victim organizations. In turn, there have been other types of studies that focus on narrative and official discourses that construct definitions of "ideal victims" of violence (s) in Colombia, suggesting that certain official readings on violence (s) may build and produce certain victim categorizations.

After having made a state of the art on French, Latin American and Colombian literature, I consider that it necessary to deepen the approaches on the construction of the victim's status through legal dispositifs such as the Victims and Land Restitution Law in Colombia. When we are interested in the construction of the victim status by the legal dispositif we do not see only a relation or a single definition of victim but a multiplicity of definitions and interactions of the actors. Indeed, there are many relationships that are created by the confrontations between the victims and the legal dispositif. These confrontations between the legal dispositif are played around the definition of an "ideal victim" in the new victim's space (Revet and Gatti, 2016). In these new victim spaces, I argued that there is a set of encounters, confrontations and interactions that can provide a better precision in the analysis.

That is why we consider necessary analyzing the discourses and the confrontation of the victims with the dispositif to analyze how the legal dispositif produces the victim. 
Studying these different versions, shows us the different struggles of knowledge and powers, even in the political space of victims. In this respect, I suggest a problematic and some empirical hypothesis.

Problematic and empirical hypothesis: How the legal dispositif "produces" the victim?

This paper aims to ask about the different ways of reappropriation of a legal category within a legal dispositif. How do the actors of the legal dispositif reappropriate a legal category and use it? How does the legal dispositif "produce" the victim?

In the collective imaginary, a law creates a category. Nevertheless, I will show that what creates this category it is not a law, but rather a dispositif with different actors that builds and continuously recreates the category of victim.

This work tests and verifies the following empirical hypotheses:

1) The moments of encounters between the legal category and the actors of the dispositif provoke a series of classification modes on the victim. This work argues, in this sense, how there is a dialectical process between the dispositif and its actors: the legal dispositif produces the victim, and in turn, the different actors of the dispositif reconstruct that category.

2) This paper shows how victims are constantly put to the test to prove their condition as victims. The process of legal, political and social recognition then passes through a policy of proof.

3) Finally, this article supports the idea that the different ways in which victims reappropriate their status, reflects the existence of a struggle of powers and knowledge within the political space, even in the political space of the victim. Struggles that could be seen as a competition between the different victims (Chaumont, 1997).

In order to verify the above-mentioned hypothesis, this paper will first present the issues of the Colombian case through the explanation of the different paradigms of transitional justice. Secondly, I will explain the extent to which the Victims and Land Restitution Law in Colombia can be considered as a legal dispositif. In the same vein, I will describe what the different ways of reappropriation of the legal category are. Third, I will analyze the main logics that influence the process of legal recognition of victims in Colombia. Finally, I will describe in a very general way, the different struggles of power and knowledge that emerge within the legal dispositif.

\section{The Colombian case in the paradigms of transitional justice}

Colombia is one of the few countries in the world to have been involved in an armed, social and political conflict for some decades (for around 50 years). The historical origins of this conflict are numerous. Historiography (Comisión Histórica del conflicto y sus víctimas) continues to debate the various factors that trigger the case and its consequences until today. Several authors argue that the current armed conflict is inherited from the Violencia period (Pécaut, 1987); others believe that it is essentially linked to the agrarian question, marked by a very uneven distribution of land (Fajardo, 2015).

Beyond the historiography, the conflict has left more than 260,000 deads, more than 7 million displaced citizens and has affected many rural communities. According to the database of the Colombian government agency for victims (Unidad de Victimas), 8,376,463 victims of the conflict currently live in Colombia (which has about 50 million inhabitants). This figure is very important and makes Colombia a special case. 
It is in this sense that, for some time, certain political transitional justice policies have been implemented in Colombia, even the conflict been still present. The Colombian case is at the center of the studies of many paradigms of transitional justice, as we will see, between the dominant paradigm and the critical paradigms of such justice.

This is how it becomes necessary to define transitional justice by looking at it from different fields. In general terms, transitional justice is formed by the set of mechanisms and instruments related to victims' rights that aim to overcome conflict or post-conflict situations (Observatorio de Restitución y Regulación de Derechos de Propiedad Rural, 2015).

\section{The dominant paradigm of Transitional Justice}

On the one hand, grey literature elaborated by international organisations, NGOs and similar institutions has defined, in its own way, what transitional justice means and what the pillars that compose it are. For instance, the International Center for Transition justice defines the transitional justice as:

a response to systematic or widespread violations of human rights. It seeks the recognition for victims and the promotion of possibilities for peace, reconciliation and democracy. Transitional justice is not a special form of justice but justice adapted to societies transforming themselves after a period of pervasive human rights abuse. In some cases, these transformations happen suddenly; in others, they may take place over many decades (ICTJ, 2008).

These definitions from grey literature represent the dominant paradigm of transitional justice. This model has four predefined pillars: truth, justice, reparation and guarantees of non-recurrence.

In particular, regarding the third pillar, "reparation", this archetype promotes what reparations to victims should be. These reparations would be of various forms: restitution, compensation, rehabilitation, satisfaction and the guarantee of non-repetition (De Greiff, 2006; Jeangène Vilmer, 2009). According to Pablo De Greiff, there are two main components to reparations: administrativetype remedies (reparations programs created by the government, for example) and reparations that are obtained through a court process (De Greiff, 2006). Therefore, there seems to be a dogma in reparation: all the victims should be repaired and they all want reparation. In the same way, in the dominant paradigm of transitional justice, the key dogma is that all victims have the right to justice or all victims want justice (Viaene, 2013).

Various are the laws, agreements and principles that reflect this dominant prototype of transitional justice in Colombia. From the Law of Justice and Peace in 2005 to the Law 1448 "Victims and Land Restitution Law" created in 2011, going through the stipulations of the Havana Peace agreements in 2016 between the Colombian government and the Revolutionary Forces of Colombia (FARC-EP), there are several concepts that engender different types of reparations (individual and collective reparations directed to the victims). For instance, there are several fundamental principles in the Law 1448 of 2011, and among them, truth, justice, reparation and guarantees of non-repetition. The administrative reparation (Unidad de Victimas) and the reparation through the courts are examples that show that the dominant archetype of transitional justice is present in the Colombian public space. 
However, there are critical paradigms that question the premises and foundations of this dominant pattern.

\section{Critical Paradigms of transitional justice}

In response to this model, there are various definitions and reflections from different scholars that question it. For Sandrine Lefranc, transitional justice is not a concept or a "good policy" (Lefranc, 2008, p. 61). According to Lefranc, transitional justice "has been forged to serve two processes: on the one hand, a process of rationalizing the model of truth commissions [...]; and on the other hand, a process of organizing an international community of transitional justice professionals"(Lefranc, 2008 , p. 62). She explains how transitional justice could be a "justifying rhetoric" to legitimize "at the same time the constitution of an expertise".

Likewise, authors such as Colombian anthropologist Alejandro Castillejo consider that the paradigm of transitional justice is based on an idea of promise and/or construction of a new imagined nation integrated into global models of neoliberal governance (Castillejo, 2017).

In these same critical approaches to transitional justice, some authors consider that within the international repertoires for the management of contemporary wars, there is the promotion of several types of devices, including the model of transitional justice (Ocampo, 2017). Thus, this transitional justice system would be accompanied by concepts like "neoliberal peace" and "humanitarianism". According to Sandro Ocampo, models of transitional justice can establish and consolidate discourses stemming from neoliberal peace such as the universalization of human rights (Ocampo, 2017, p. 208) and the idea that it is not possible to refute them because they have become "the common (or vernacular) language of global moral thought" (Ocampo, 2017, p. 208). According to Oliver Richmond (2002), the comprehension of peace is of a neoliberal conception that promotes the exit of the conflict through the State: Richmond therefore states that there is a statocentrism and a maintenance of the means of economic mediation, including peace officers associated with the neoliberalisation of war and peace affairs. Hence, Akhil Gupta (2006) and Sandro Ocampo point out that the expansion of the world of NGOs, foundations and philanthropists reflects that the conflict zones are seen as a peace market, which Kimberly Theidon calls "Transitional Justice Industry" (Ocampo, 210), and Alejandro Castillejo calls the "testimony industry" (2009).

In this same critical approach, Diana Marcela Gómez Correal considers that transitional justice systems reproduce logics of domination that are integrated into global capitalism (Gómez Correal, 2016). This model of transitional justice pursues the logic of the domination of the modernity / Western colonialism (Gómez Correal, 2016). This critique of modernity and colonialism is pursuing critics from post-developmentalism circles that question neoliberal transitions and the concept of development. Gómez Correal relies in particular on Arturo Escobar, a Colombian anthropologist who is interested in the criticism of modernity and the notion of development. According to Escobar, it is necessary to create ontological news (Escobar, 2018, p. 94) that go beyond the dualistic conception of the world (nature/culture, human/non-human).

In addition, for some researchers, this dominant paradigm tends to omit the role of traditional justice in transitional justice (Viaene, 2013, p. 90). In Guatemala, although the war has partially destroyed the basic principles of traditional justice, many communities are using them to lay the groundwork for new coexistence practices (Beristain, 1999, p. 137). 
In the Colombian case, for some authors Colombia can become "a laboratory where indigenous peoples transcend the limits and practices of the dominant paradigm of transitional justice" (Giraldo and Viaene, 2018). In fact, according to Belkis Giraldo and Lieselotte Viaene, on a legal level, Colombia has demonstrated the will to decolonize transitional justice by incorporating visions that were historically silenced or marginalized, such as the cosmovisions of indigenous and Afrodescendant peoples. For example, the "Justicia Especial para la Paz" (Special Justice for Peace) an entity that is part of the Integral System of Truth, Justice and Reparation and created by the Havana Peace agreements (2016) - promotes restorative justice and has integrated "principles, logics and rationalities of the justice system of ethnic people". Beyond the theoretical, the implementation of these principles is fundamental for communities that have been marginalized for a long time in Colombia.

In this sense, we will see how the different models presented above are relevant to understanding the functioning of the reparation and classification policies of victims in the transitional justice processes in Colombia. The notion of device will be useful to understand the production process of the victim.

\section{The Victims and Land Restitution Law in Colombia (VLRL) as legal dispositif}

From a Foucauldian perspective, we consider this law as a dispositif composed of an assembly or "heterogeneous ensemble" of various elements (Foucault, 2001, p. 299). This notion, coined by Michel Foucault in the 1970s, is defined as

a thoroughly heterogeneous ensemble consisting of discourses, institutions, architectural forms, regulatory decisions, laws, administrative measures, scientific statements, philosophical, moral and philanthropic propositions - in short, the said as much as the unsaid. Such are the elements of the apparatus. The apparatus itself is the system of relations that can be established between these elements (Foucault, 2001, p. 299).

For Foucault, the dispositif is a historical formation, which is constantly readjusted to the interactions (or play) of its components. This historical training is accompanied or guided by a dominant strategic function, which aims to respond to one or several social "emergencies". In Discipline and Punish, Foucault explains how the disciplinary dispositif arises from the social need to "control and channel" (Silva Castañeda, 2012, p. 96) a mass of wandering population in the XVIII century. This is how these objectives or functions strategic outcomes may produce anticipated or unintended effects. The set of heterogeneous elements of the network thus produces knowledge and practices that are at the origin of the forces relationships within the dispositif. There are therefore struggles of knowledge and constant powers within the dispositif.

As a legal dispositif, the Victims and Land Restitution Law produces several anticipated and unforeseen effects. Among the first are its important strategic function: that of fully repairing the consequences of the armed conflict in Colombia.

Our interest in this paper is to concentrate on the interactions between the actors and this legal dispositif through a normative work (Barbot and Dodier, 2016): this asks to explore the perceptions of actors on what they consider themselves to be and not to be. The actors of the legal dispositif, are 
in this case: civil servants or public servants (high ranking official or street bureaucrats) (Lipski,1980), the victims, associations of victims or associations defending the causes of victims.

The SNARIV (National System of Integral Assistance and Reparation to Victims) can be considered as a legal dispositif composed of many heterogeneous elements. In this sense, the law of victims, the public windows, the technical tools, the technological platforms, the buildings, the different actors and other elements, illustrate the existence of a set of different elements.

The SNARIV institutions are organized in a division of labour (Street level bureaucracy) that operates through two main agencies: the Victims Unit (UV) and the Land Restitution Unit (LRT). The Victims Unit is responsible for the coordination of the SNARIV, and the Land Restitution Unit for the restitution of land to the victims. The legal recognition of the victim status requires going through various administrative stages. State agencies such as the Victims Unit and the Land Restitution Unit are fundamental institutions for the acquisition of legal status. Street level bureaucracy officers are policymakers who are responsible for applying the law in the national territory. The street bureaucrats, in this case the public servants of the Public Prosecutor's Office found in the field, have as their main objective to collect the statements of the victims to see if they are included in the National Registry of Victims. These officials transmit these statements to the Victims Unit in Bogotá. Depending to what the officials found on the field, the Victims Unit in Bogotá administers the received declarations and decides on the registration in the Unified Registry of Victims. Local agencies are intermediary agencies between the Victims Unit and the victims, who still have an important role in the dispositif. The local agencies have a certain margin of manoeuvre, but despite the degree of deconcentration of the law, the SNARIV continues to be very centralized. This centralization has a fundamental effect on the conditions of attribution of victim status.

\section{Classification modes: between the "ideal victim" and the suspected victim}

The different encounters within the dispositif produce different ways of reappropriation of the legal category of victim. These modes of reappropriation depend on the social position of actors inside of the dispositif, as well as on the circumstances of the encounters within the dispositif itself. In the field I was able to identify two types of imaginaries about the victims: on the one hand, the actors of the dispositif construct the figure of an ideal victim; and on the other hand, they build the figure of a suspected victim.

On one hand, I could see on the field ${ }^{1}$ that there is an ideal victim who is classified as humble and grateful.

Many victims are poor and find themselves in conditions precarious. The characteristics of these victims, according to the officials, place them in a constant vulnerability: illiterate victims, uneducated victims with primary or secondary education, or the country's "historical poor". According to several officials, fraudsters take advantage of the fact that some peasant victims can neither read nor write:

Johanna: There are people who can not read. Since they can not read, rather the peasants, the people take advantage of them, they give them half the compensation and make them sign papers. Then these people were telling the victim to come later.

\footnotetext{
${ }^{1}$ Interviews conducted in the field in 2017, Colombia.
} 
After the victims came and told us, "They gave us this and we signed". I asked them, "Why did you sign this, do not sign!" And that's how it is that they had been robbed. There were other victims who had drug-addicted children, for example one day one lady came here to cry:

'It's because my son takes 5000, 3000 pesos from me. He says he's going to recharge money on his mobile to write or send an SMS to the Victims Unit.'

They tell me, they can not read².

Johanna considers that there are victims who are abused and are still in a vulnerable condition, because of their low level of education and their age. In the land jurisdiction, there is also a vision on the victims of the VLRL, especially the peasant victims and illiterate. Gloria and Pedro consider that there is an imbrication between the displaced and the "Historic poors" in Colombia:

Gloria: The purpose of the restitution is to repair the victim but also to build a firm and a lasting peace, that farmers do not find the same conditions of economic precariousness, because many of the displaced are historically poor. We want them to have opportunities to economic stabilization, the opportunity to do a project without causing harm to others poor and vulnerable peasant communities in the $\operatorname{area}^{3}$.

Victims are also expected to be humble and grateful to administration. According to the officials interviewed, the peasant victims would be very grateful victims. Manuel who had contact with the victims even after the restitution of their land, told us that sometimes he was invited home and they gave vegetables and fruits to bring home:

Autor: Are you still in touch with the victims?

Manuel: No, it's been a long time since no. Anyway when I go to the LRT, I see victims. There are victims who remember me. I have a good relationship with them. Autor: You do not see them in the field, but rather outside, in everyday life.

Manuel: Then all the victims tell me "Come to my finca". Once, I went to one of these fincas. This farm did not have energy. It was cool. I did not pick up a phone signal over there. Sometimes I really like relaxing in the country. The victims treated me very well.

Autor: Excellent.

Manuel: there are some victims who have productive projects. I was going to see them. Sometimes I arrived at my house with a lot of fruit.

Autor: the victims offer you the fruits.

Manuel: Clusters, clusters of plantain, lots of plantain clusters. I arrived in my $4 x 4$ and I told my parents "Dad, mom, please, help me down the fruit". We had bags of plantain, yuccas ${ }^{4}$, oranges, mandarins. That day the victims told me "Pack these fruits for your house",

\footnotetext{
${ }^{2}$ Collective interview conducted on January 17, 2017 in Dagua, Colombia.

${ }^{3}$ Interview conducted on February 21, 2017 at the Specialized Land Restitution Court of Second Instance in Cali, Colombia.

4 Type of cassava grown in Latin America.

${ }^{5}$ Interview conducted on 23 February 2017 in Cali, Colombia.
} 
These meetings between the legal dispositif and the officials build clear-cut visions of those victims who should be repaired: "poor" victims, humble and very grateful. Imaginaries that highlight the power relations between civil servants and victims.

\section{A process of legal recognition that goes through a classification, waiting and testing}

The construction of an ex-ante definition of the "ideal" victim by the bureaucrats goes in hand with the process of legal recognition. This process is translated in a set of three policies: a classification policy, a waiting policy, and a policy based on the "proof".

On the one hand, officials of the victims' law through a classification policy, are responsible for selecting and discarding the dossiers according to the degree of their relevance. The selection is done on several non-legal and legal criteria. In this sense, this classification policy is accompanied by different tactics to distinguish who is a victim and who is not.

The classification policy carried out at the counters is a reflection of suspicion as a form of coercion: not only are individuals classified, but so are the documents that accompany them. Taking into account the large number of victims who arrive at the counter, suspicion becomes the norm. In turn, the process of legal inclusion is translated by a policy of proof and waiting for the victims. The victims we interviewed are constantly put to the test to prove their victim status. Good faith promulgated by law is not enough. The provision of tangible evidence is essential to obtain the legal status. In the case of the victims of dispossession or forced abandonment, the victims must testify to the damages and suffering suffered in the conflict.

This policy based on "proof" is imposed in different phases of the legal dispositif. In order to receive humanitarian aid and administrative compensation, victims must prove their condition as victims and the precarious situation in which they live. This policy is characterized by constant situations of uncertainty and unpredictability. The victim does not know when it will be included in the National Registry of Victims.

The victim is then in a perpetual wait to obtain a response from the Victim Unit in Bogotá: victims contacted in the field ${ }^{6}$, must make several comings and goings, several phone calls, send several text messages, even talk to an official via chat, to be able to follow your case. Waiting in the wickets has been considered by some sociologists as a mechanism of domination (Damin, 2014, p. 408) by the state towards these citizens. Javier Auyero, in his Patients of the State book shows us how waiting rooms could become political environments (Auyero, 2011).

These mechanisms of domination would not only reduce citizens to "passive subjects", but turn them into active subjects who exercise open resistance. The fieldwork showed how, through the speeches of the victims, it is a clear policy of waiting that takes place in the windows of the VRLR.

Victims are aware of these dysfunctions: both in Dagua and Cali, observations and interviews have confirmed this, with expressions such as: "If I go today I'm going to lose a whole day" or "I know I'm going to sit all day, there". Victims who must file their statement for the first time are

\footnotetext{
${ }^{6}$ Notes from the field notebook and interviews on the field, Distrito de Aguablanca, 2017.

${ }^{7}$ Expression listened constantly to Jueves de Paz.
} 
warned in advance by those who have already experienced the waiting room experience. Here is a dialogue between two victims in a $\mathrm{CRAV}^{8}$ waiting room, which I noted:

- How long does the statement take and all that?

- If this is the first time you come to make your statement, it will take you at least three hours. You will go through several offices.

- Ah yes?

- Yes, if you had your appointment at nine o'clock, you will go out at about 13 o'clock or less'.

Moreover, this waiting policy is characterized by uncertainty and the unpredictability of the device. Uncertainty in the sense that the victim does not know the fate that will be reserved for her file: it may result in inclusion in the National Registry of Victims as a refusal, or still lag behind humanitarian aid. Unpredictability, in the sense that victims can not predict how much time may elapse before the remedial measures are effective.

The waiting policy is essentially organized in a waiting room, by the delivery of waiting tickets inside a building such as the CRAV. In the case of CRAV, the waiting is divided by different floors. Every waiting in the waiting room, the victims interact with each other. They tell each other the story of their life and also where we go their record. At the same time as they wait their turn, they laugh, they chatter. The waiting room is not a solemn place where silence is the norm. In waiting rooms, the victims symbolically, yet actively, participate in open and even festive resistance. These forms of resistance are discrete or even distant. These forms of sub-political resistance are a reflection of intermittent politicization as there is forms of domination that openly occurs at the box office. On the contrary, the room becomes a place of knowledge and exchange. In parallel, the victims are attentive to what each person respects their turn. They are vigilant and want everyone to respect the waiting time. The one who doubles the line is punished: the victims call them and ask them to line up like everyone else. All in all, these waiting places become places of intermittent politicization.

\section{In search of recognition: a struggle of powers and knowledge in the legal dispositif}

\section{The different policies show the different expectations that victims have of the VLRL}

The victims encountered have expectations regarding the dispositif. Normative expectations are the assessments that individuals make the dispositif. Barbot and Dodier define normative expectations as "the evaluations, positive or negative, that individuals explicitly bear on states of affairs" (Barbot and Dodier, 2016, p. 426). According to these authors, any evaluation refers to normative expectations. Barbot and Dodier synthesize the various judgments made by victims with regard to the medical repair dispositif. Through these different judgments, Barbot and Dodier, have identified three normative expectations of the victims: the reparation, which is based on the capacity of the dispositif to cover economically the damages caused by the disease; the expectation of justice, as "the manifestation of moral responsibilities in the occurrence of the tragedy" (Barbot and Dodier, 2016,

\footnotetext{
${ }^{8}$ Centro Regional de Atención a Victimas (Regional Support Center to the victims), is a set of state agencies that are responsible for repairs and assistance to victims.

${ }^{9}$ Notes of the field notebook of March 7, 2017 at CRAV in Cali.
} 
p. 442); and finally, the expectation of adjusted compensation, regarding the meaning that compensation as compensation for their damage. In the case of VRLR, the fieldwork illustrates how these expectations go beyond repair, justice and adjusted compensation.

\section{Justice according the victims}

Justice is another normative expectation of the victims. Beyond the reparation, several victims from different social classes want to know the motivations of those who harmed them. They want to know what really happened in the past, why they were targeted. In particular, victims of state crimes (MOVICE, 2017) want know who is responsible for the deaths of their loved ones, and in some cases, know the place where the bodies are buried. Justice is accompanied by a demand for truth. Maria Elena, a victim whose husband was killed, wants to know more about this assassination. Her husband was a lawyer, human rights defender, who regularly pleaded for political prisoners of a group. She told me of the need for justice and truth for the death of her husband:

After Jesus' death in January, I received a death threat at home. My eldest son found an envelope with this threat. Despite the insistence of my children not to denounce this situation, I realized a criminal complaint to the public prosecutor, I handed them the envelope. This threat said "do not build yourself in civil party because you will have the same consequences". Becoming a civil party refers to the right of victims to know the truth. It is a request for justice because of the damage caused ${ }^{10}$.

Moreover, as Barbot and Dodier also explain, several victims, particularly those of land restitution, are seeking "adjusted compensation" for the quality of the improvements they had made on their lands. In the process of restitution of lands, there may be disagreements between victims and judges over compensation monetary policy. For some victims, the compensation given is neither sufficient nor comparable to their finca. A victim who abandoned his finca and started a trial to reclaim it, told me that because security conditions are always bad, the State can no longer assure him the return to his land. The state offered a compensation to this victim and gave him a finca comparable to that abandoned. Nevertheless, the victim tells me that he does not want another finca but the one he has abandoned. As a result, there are power struggles between victims and judges about the amount of compensation they believe to be the best fit. These struggles are at the origin unequal relations between the victim and the judge, being the latter, the one who decides the decision final. According to the victim, in his case compensation becomes difficult because of from his attachment to his land. Adjusted compensation is also an expectation for victims who would like to receive more resources in humanitarian aid.

This expectation of adjusted compensation causes economic distinctions between victims. Indeed, some victims feel scorned by those who have already been compensated because they become economically well off. Not receiving humanitarian aid commensurate with their needs results in a comparison between the victims. Justifying speeches and even justifying grammars (Boltanski and Thévenot, 1991) appear in victims' speeches. According to Boltanski and Thevenot, explaining and justifying oneself is part of everyday life. According to these authors, one of the constant traits in

\footnotetext{
${ }^{10}$ Interview conducted on 7 March 2017 in Cali, Colombia.
} 
human relations is to justify oneself, with the imperative of giving explanations based on the principle, or sense of justice. Senses of justice and normality emerge from their discourse.

Here, the victims encountered felt that their sense of justice was offended because they were compensated to a lesser extent than the others or because they receive less humanitarian aid. These victims' speeches are not just rhetoric, there is indirect competition to see who is more legitimate than the other to receive more reparation.

In the field I found some type distinctions between the victims. These economic distinctions are more or less visible depending on the stage of the process of legal recognition of the legal dispositif. Regarding the distribution and payment of humanitarian aid for the displaced, several victims encountered questioned the sum given by the UV to certain victims. The number of children of a victim family could play in this distinction between the victims. In a session of Jueves de Paz ${ }^{11}$, a victim told me: "I know a family that has been given more money than me. I have more children and more their needs, and they received more. I have 4 kids, I do not have a job and I rented a house. I do not understand why we gave more to them than $\mathrm{me}^{12}$.

Finally, there are expectations of tranquillity and peace. The majority of the victims I spoke to in Aguablanca told me that they simply wanted to "live in peace and tranquillity", or to be able to live off their work, with the help of the State.

\section{Conclusion}

This work used theoretically the notion of dispositif as a way to understand the different meetings between the various actors of the VRLR. The notion of dispositif has helped to link the different studies previously carried out on the subject of victims in Colombia. The dispositif has further allowed to study the interstices between different spaces of the victim's cause. Considering the VRLR as a legal dispositif allowed us to approach the various elements that are put in place during the procedure recognition of the legal status of victims. As I have argued, these processes of recognition come from an assembly mobilizing actors (victims and officials of the branch, mainly), agencies (Public Prosecutor's Office, Victims' Agencies, restitution of land), giving rise to administrative measures (application forms registration), legal texts (law and decrees), technical tools (RUV), the layout of buildings (the CRAV, the counter, mainly). This process takes place in public as well as private spaces: in neighbourhood associations, closer to the victim's daily life; in the waiting rooms of the agencies of victims; in front of the clerk or the judge. The waiting room is the main meeting place between several types of victims and official institutions.

Similarly, the use of the dispositif allowed to shed light on the relationships of domination that emerge in the interactions between the victims and the other actors of the dispositif. Each actor produces modes of classification of the victims, resulting for example from the balance of power between the counter staff and the victims, between the latter and the victim's foundation they frequent.

Both Street Level Bureaucracy officials, associations and victims themselves recreate the legal status presented by the dispositif.

\footnotetext{
${ }^{11}$ A project of a foundation that works with victims in Cali where I volunteered between January and March.

${ }^{12}$ Unregistered and Restored Interview of February 2, 2017 at Marroquin II, Cali.
} 
The space of the victim or the space of the victim's cause (Lecombe, 2014) has been expanded in recent years in Latin America and in the world. The universe of the victim was commonly sacred: only "martyred" or emblematic victims were accepted and recognized as belonging to the universe of the victim. The opening of said universe generated the entrance of other individuals in the "space for the cause of the victim". Both "ordinary" and "anonymous" victims began to enter on that space. How has the universe of victims expanded in recent years, especially in Colombia?

Transitional justice, among other causes, has led to an expansion of the victim's universe. In the Colombian case, the law of Victims and Land Restitution has expanded the universe of the victims: from the victims "martyrs" and the emblematic victims to the ordinary and sacred victims are part of the new space of the victims. This legal dispositif "the law of victims and restitution of lands" goes beyond the sacred or emblematic victims. Indeed, there is an expansion of the universe of victims through the insertion of new victims (ordinary and anonymous). These ordinary and anonymous victims are part of those victims who have never been recognized in the formal political space (political institutions, mass media or legal dispositifs).

\section{References}

AUYERO, Javier. Patients of the State. An Ethnographic account of poor people's waiting, Latin American Research Review, v. 46, n. 1, p. 5-29, 2011.

BARBOT, Janine; DODIER, Nicolas. Repenser la place des victimes au procès pénal. Le répertoire normatif des juriste en France et aux États-Unis. Revue Française de Science Politique, v. 64, p. 407-433, 2014.

BERISTAIN, Carlos. Intervención de Carlos Martín Beristain. In: Memorias del Seminario internacional Verdad y Justicia en Proceso de Paz o Transición a la Democracia, Oficina en Colombia del Alto Comisionado de Naciones Unidas para los Derechos Humanos, 1999

BOLTANSKI, Luc; THÉVENOT, Laurent. De la Justification: les économies de la grandeur. Paris: Gallimard, 1991

CASTILLEJO, Alejandro. La Ilusión de la Justicia Transicional: Reflexiones desde el Sur Global. Bogotá: Ediciones Uniandes, 2017 . Los archivos del dolor. Bogotá: Ediciones Uniandes, 2009

CEPEDA VARGAS, Ivan. Genocidio político: el caso de la Unión Patriótica en Colombia. Revista CEJIL Debates sobre Derechos humanos y Sistema Interamericano, año 1, n. 2, p. 101-112, 2006

CHAUMONT, Jean Michel. La concurrence des victimes. Génocide, identité, reconnaissance. Paris: La Découverte, 1997.

DAMIN, Nicolas. El Estado, la espera y la dominación política en los sectores populares: entrevista al sociólogo Javier Auyero. Salud Colectiva, v. 10, n. 3, p. 407-415, 2014.

DE GREIFF, Paulo. The handbook of reparations. Oxford: Oxford University Press, 2006. 
ESCOBAR, Arturo. Sentir-Penser avec la Terre. Une écologie politique au-delà de l'Occident. Paris: Editions du Seuil, 2018.

FAJARDO, Dario. Estudios sobre los orígenes del conflicto social armado, razones de su persistencia y sus efectos más profundos en la sociedad colombiana In: PIZARRO, Eduardo; MONCAYO, Victor (Relatores). Contribución al entendimiento del conflicto armado en Colombia de la Comisión histórica del conflicto y sus víctimas. Bogotá: Ediciones Desde Abajo, 2015.

FOUCAULT, Michel. Le jeu de Michel Foucault. In: Dits et écrits Tome III, texte n. 206. Paris: Gallimard, 2001.

GATTI, Gabriel; REVET, Sandrine. Victimes cherchent statut désespérément: le cas des "bébés volés" en Espagne. Critique internationale, n. 72, p. 93-111, 2016.

GIRALDO, Belkis; VIAENE, Lieselotte. Descolonizar la justicia transicional desde los territorios indígenas. Peace in Progress, n. 34, s.p., 2018.

GÓMEZ CORREAL, Diana. El encantamiento de la la justicia transitional en la actual coyuntura colombiana: entre disputas ontológicas en curso. In: PARDO ABRIL, Graciela; RUIZ CELIS, Juan (Eds.). Victimas, memoria y justicia: aproximaciones latinoamericanas al caso colombiano. Bogotá: Ediciones UNAL, 2016.

GUPTA, Akhil. Blurred Bounderies: Discourse of Corruption, The Culture of Politics, and Imaginate State. In: GUPTA, Akhil; SHARMA, Aradhana (Eds.). The Anthropology of the State: a reader. New Jersey: Blackwell, 2006.

INTERNATIONAL CENTER FOR TRANSITIONAL JUSTICE. What is transitional justice? [Online]. 2008. Available in: https://www.ictj.org/sites/ default/files/ICTJ-Global- TransitionalJustice-2009- English.pdf>. Access in: 20 Apr. 2019.

JARAMILLO, Jefferson. Las comisiones de estudio sobre la violencia en Colombia. Un examen a los dispositivos y narrativas oficiales sobre el pasado y presente de la violencia. In: ALLIER MONTAÑO, Eugenia; CRENZEL, Emilio (Eds.). Las luchas de las memorias en América Latina. Historia reciente y violencia política. Ciudad de México: Bonilla Artiga Editores, 2015.

JEANGÈNE VILMER, Jean-Bapiste. Réparer l'irréparable: Les réparations aux victimes devant la Cour Pénale Internationale. Paris: Puf, 2016.

LECOMBE, Delphine. "Nous sommes tous en faveur des victimes", la diffusion de la justice transitionnelle en Colombie. Paris: Institut Universitaire des Varennes, 2014.

LEFRANC, Sandrine; MATHIEU, Lilian. Mobilisations de victims. Rennes: Presses Universitaires de Rennes, 2009.

. La justice transitionnelle n'est pas un concept. Mouvements, n. 53, p. 61-69, 2008.

LIPSKY, Michael. The critical role of Street level bureaucrats. In: . Street level bureaucracy. Dilemmas of the individual public services. New York: Russel Sage Foundation, 1980.

MOVIMIENTO NACIONAL DE VÍCTIMAS DE CRÍMENES DE ESTADO. 148 organizaciones y 16 personalidades expresan ante la C. Constitucional su apoyo a la Comisión para el Esclarecimiento de la Verdad [Online]. 2017. Disponible en:

$\mathrm{http}: / / \mathrm{www} . m o v i m i e n t o d e v i c t i m a s . o r g / ? \mathrm{q}=$ content/148eorganizacioneseye 16epersonalidadeseexpre saneanteelaecconstitucionalesueapoyoelaecomisi\%C3\%B3n. Acceso en: 16 mayo 2017. 
OBSERVATORIO DE RESTITUCIÓN Y REGULACIÓN DE DERECHOS DE PROPIEDAD RURAL. Informe sobre el estado actual e impactos del proceso de restitución de tierras en Montes de María [Online]. Primer Reporte Semestral 2015, 2015. Available in: http://www.

observatoriodetierras.org/wp- content/uploads/2014/01/ Reporte-Semestral-2015.1- Impacto-de-laRestituci\%C3\% B3n-en-Montes-de-Mar\%C3\%ADa.pdf. Access in: 22 Jul. 2019.

OCAMPO, Sandro. Crisis en las nociones, los mecanismos institucionales y la investigación social sobre el conflicto en Colombia. Más allá del humanitarismo transicional y la paz liberal. In:

CASTILLEJO, Alejandro (Comp.). La Ilusión de la Justicia Transicional: Reflexiones desde el Sur Global. Bogotá: Ediciones Uniandes, 2017.

PÉCAUT, Daniel. L'ordre et la violence. Evolution socio-politique de la Colombie entre 1930 et 1953. Paris: Editions de l'Ecole des Hautes études en Sciences Sociales, 1987.

RICHMOND, Oliver. Maintaining Order, Maiking Peace. New York: Palgrave, 2002.

SCHELOTTO, Magdalena. La dictadura cívico militar uruguaya (1973-1985): la construcción de la noción de víctima y la figura del exiliado en el Uruguay post dictatorial. Nuevo Mundo Mundos Nuevos - Cuestiones del Tiempo presente, 10 mar. 2015.

SILVA CASTAÑEDA, Laura. Revisiter le concept de dispositif. À partir d'un dialogue entre la sociologie pragmatique et la pensée foucauldienne. Revue de l'Institut de Sociologie, p. 91-107, 2012.

TRAÏNI, Christophe. Les victimes entre émotions et strategies. In: LEFRANC, Sandrine; MATHIEU, Lilian (Dir.). Mobilisations de victims. Rennes: PUR, 2009.

VIAENE, Lieselotte. La Relevancia local de procesos de justicia transicional. Voces sobrevivientes indígenas sobre justicia y reconciliación en Guatemala Posconflicto. Antípoda. Revista de Antropología y Arqueología, n. 16, p. 85-112, 2013.

\author{
Artigo recebido em: Abril/2019 \\ Artigo aprovado em: Junho/2019
}

\begin{abstract}
Alma Cielo Ochoa Sterling (alma.ochoasterling@gmail.com) é Mestre em Desenvolvimento Local e em Direito Constituicional e Direitos Fundamentais pela

Université Paris I - Panthéon Sorbonne/França.
\end{abstract}

\title{
The Construction of the Status of "Victim" through the Victims and Land Restitution Law in Colombia - (re)encounters and confrontations with a legal category
}

\begin{abstract}
Studying the victim as an object of analysis in the social and political sciences has produced many epistemological debates. In the present work, we try to study the construction of the status of the victim through a specific legal dispositif: The Law of Victims and Restitution Of Lands in Colombia (VRLV, Law 1448 of 2011). We will ask ourselves: how does the legal dispositif produce "the victim"? Accordingly, we will analyse how the construction of the victim's status not only passes through the self-identification of the individual as a victim, and through the recognition of the victim by the government but is also included in a process of collective and contested victimization. This
\end{abstract}


process of victimization encompasses a series of encounters and confrontations between the dispositif and the actors of the "victim's" universe. In said victimisation process there is a struggle of knowledge (of what) and powers, which call into question the definition of violence in post-conflict societies. Keywords: Victim; Armed Conflict; Law; Legal Category; Recognition; Transitional Justice.

\section{A Construção do Status de "Vítima" através da Lei de Vítimas e Restituição de Terras na Colômbia - (re)encontros e confrontos com uma categoria legal}

Resumo. Estudar a vítima como objeto de análise nas ciências sociais e políticas produziu muitos debates epistemológicos. No presente trabalho, procuramos estudar a construção do status da vítima por meio de um dispositivo legal específico: a Lei das Vítimas e a Restituição de Terras na Colômbia (VRLV, Lei 1448 de 2011). Perguntaremos a nós mesmos: como o dispositivo legal produz "a vítima"? Nesse sentido, analisaremos como a construção do status da vítima passa não só pela auto identificação do indivíduo como vítima, e pelo reconhecimento da vítima pelo governo, mas também está incluída em um processo de vitimização coletiva e contestada. Esse processo de vitimização engloba uma série de encontros e confrontos entre o dispositivo e os atores do universo da "vítima". No referido processo de vitimização, existe uma luta de conhecimento (de quê) e de poderes, que põe em causa a definição de violência nas sociedades pós-conflito.

Palavras-Chave: Vítima; Conflito Armado; Lei; Categria Legal; Reconhecimento; Justiça de Transição. 